\title{
Assuring Equality, Autonomy and Territorial Integrity in Sri Lanka
}

\author{
Jayampathy Wickramaratne
}

On 9 March 2016, the Sri Lankan Parliament unanimously passed a resolution for setting up a Constitutional Assembly consisting of all 225 Members of Parliament tasked with preparing a draft of a Constitution Bill for the consideration of Parliament. ${ }^{1}$ If a two-thirds majority of the Assembly had approved the constitutional draft proposal within one month, the same would have been submitted to the Cabinet of Ministers. Thereafter, the Cabinet would have presented the draft in the form of a Bill to Parliament. Under the present Constitution, an amendment of the Constitution ordinarily required a twothirds majority in Parliament. ${ }^{2}$ Article 83 of the Constitution provided that a Bill aiming at amending, repealing or replacing, or that was inconsistent with any of the provisions of Articles 1 (The State), 2 (Unitary State), 3 (Sovereignty of the People), 6 (National Flag), 7 (National Anthem), 8 (National Day), 9 (Buddhism), 10 (Freedom of thought, conscience and religion), 11 (Freedom from torture), Article 83 itself and also a Bill that sought to extend the term of office of the President or the duration of Parliament to over six years, would become law only if passed by a two-thirds majority in Parliament and approved by the people at a referendum. Thus, it necessarily followed that a new Constitution required passage in Parliament by a two-thirds majority followed by approval at a referendum.

A twenty-one-member Steering Committee containing all political parties represented in Parliament and chaired by the Prime Minister was appointed. Six all-party subcommittees were appointed to make proposals on fundamental and language rights, judiciary, law and order, public service, public finance and centre-periphery relations. Their reports were presented on

1 Parliament of Sri Lanka, "Resolution for the Appointment of the Constitutional Assembly," (9 March 2016), https://parliament.lk/uploads/documents/minutesofparliament/1509078170042858.pdf.

2 Article 82 (5) of the Constitution. 
19 November 2016. The interim report of the Steering Committee was presented to the Constitutional Assembly on 21 September 2017. ${ }^{3}$ It covered the following areas: nature of the state, nature of the executive, parliamentary electoral process, principles of devolution, religion and state land. While the report represented the dominant view in the Steering Committee, observations and comments by members of the Steering Committee on the principles and formulations contained in the report were also included in it. ${ }^{4}$

The next step should have been a general debate on the reports in the Constitutional Assembly. Thereafter, the Steering Committee might have considered views expressed during the debate and the public discussion that had already begun and then presented its final report along with the draft constitutional proposal envisaged in the parliamentary resolution. However, very little happened after the Steering Committee submitted its interim report except that the panel of experts submitted a 'legal draft' based on the interim report and the reports of the various sub-committees.

It will be helpful for readers to have some insight into the history of Sri Lanka's ethnic conflict, and the various attempts for a resolution. The Sri Lankan story is one of missed opportunities, by both the Sinhalese and Tamils. For Sri Lanka, the war is over, but the conflict is not. Only a settlement that offers all communities their due share of state power within a democratic framework can end the conflict - a truism for most observers but, sadly, not so for all Sri Lankans. ${ }^{5}$

\section{$2 \quad$ Demography}

Sri Lanka is a multi-cultural society with four major communities - Sinhalese, Tamils, Muslims and Hill Country Tamils. According to the 2012 census, ${ }^{6}$ the

3 Steering Committee, "The Constitutional Assembly of Sri Lanka, The Interim Report of the Steering Committee," http://constitutionnet.org/sites/default/files/2017-og/Interim\%2o Report\%2oof\%2othe\%2oSteering\%2oCommmittee\%2oof\%2othe\%2oConstitutional\%2o Assembly\%20of\%2oSri\%2OLanka_21\%2oSeptember\%202017.pdf, accessed on 12 August 2017.

4 Ibid 27-92.

5 For a detailed discussion see Jayampathy Wickramaratne, "Sri Lanka: Missed Opportunities and the Way Forward," in Towards Democratic Governance in Sri Lanka: A Constitutional Miscellany, ed. Jayampathy Wickramaratne (Rajagiriya: Institute for Constitutional Studies, 2014), 485-548.

6 Department of Census and Statistics of Sri Lanka, "Census of Population and Housing of Sri Lanka, 2012," http://www.statistics.gov.lk/PopHouSat/CPH2011/Pages/Activities/Reports/ FinalReport/Population/Table\%2oA3.pdf, accessed 12 August 2020. 
Sinhalese make up $74.9 \%$ of the total population of a little over 20 million. They are concentrated in the densely populated south-west as well as the central parts of the country. ${ }^{7}$ Sri Lankan Tamils constitute $11.2 \%$ of the population and mainly live geographically concentrated in the Northern Province and in parts of the Eastern Province. Moors, descendants of Arabs who settled in Sri Lanka, represent $9.2 \%$ of the total population. They live in substantial numbers in the east and are also found in other parts of the country, mostly concentrated in urban areas. In recent times, their identity has been more as Muslims rather than as Moors. ${ }^{8}$ Hill Country Tamils are a distinct ethnic group and descend from those brought from India by the British in the nineteenth and twentieth centuries to work in the plantations. They are referred to as Indian Tamils in official records, but most prefer to call themselves Hill Country Tamils. They comprise $4.2 \%$ of the population and live in significant numbers in the Central, Uva and Sabaragamuwa Provinces. In the Central Province, Hill Country Tamils dominate the Nuwara Eliya District (53.2\%). There are also small numbers of Malays, Burghers (descendants of Europeans) and indigenous Veddhas. The native language of the Sinhalese is Sinhala while that of Tamils, Muslims and Hill Country Tamils is Tamil.

The North and East have been the stage of ethno-political conflict in the country. Sri Lankan Tamils constitute almost $95 \%$ of the population of the Northern Province. The issue is compounded by the population distribution in the Eastern Province. In the Trincomalee district, which is adjacent to the Northern Province, all three major communities constitute substantial percentages: $27 \%$ Sinhalese, $30.6 \%$ Tamils and $40.4 \%$ Muslims. The Batticaloa district, south of Trincomalee, is predominantly Tamil (72.6 \%) with $25.5 \%$ Muslims, but has no boundary with the North. The Ampara district, further to the South, has $43.6 \%$ Muslims, $38.7 \%$ Sinhalese and $1.4 \%$ Tamils. The Sinhalese live mainly in the Ampara electoral division, which is adjacent to the Sinhala-dominated Uva Province. The other three electoral divisions of the district, namely, Kalmunai, Sammanthurai and Pottuvil, together have a Muslim population of around $59 \%$ with $27 \%$ Tamils and $14 \%$ Sinhalese.

Religion-wise, $70 \%$ of the country's population is Buddhist, while Hindus represent $15 \%$, and Christians (the large majority of whom are Roman

7 For a political map, see https://www.mapsofworld.com/sri-lanka/sri-lanka-political-map. html, accessed on 24 June 2019 .

8 For the purpose of Sri Lankan census and statistics, Moors are recognised as an ethnic group. Malays and people of Indian origin such as Memons, Bohras and Khojas are Muslims but have no Arab ancestry. 
Catholics) and Muslims 7.5 \% each. The large majority of Sinhalese are Buddhists, with $6.6 \%$ being Christians; the large majority of Tamils and Hill Country Tamils are Hindus, with Christians amongst them being $19.2 \%$ and $10.1 \%$ respectively. 9

The demography of Sri Lanka is thus complex, with both concentrated as well as dispersed communities. The challenge in such circumstances is to adopt a constitution that gives all communities their due share of state power.

\section{Brief History of the Conflict}

It was not the Tamils but Solomon W.R.D. Bandaranaike, who was later to form the pro-Sinhala Sri Lanka Freedom Party (SLFP) and become Prime Minister, who first proposed a federal Constitution for Sri Lanka. He did so in six articles he wrote for the Ceylon Morning Leader ${ }^{10}$ and in a public lecture in Jaffna, ${ }^{11}$ all in 1926 .

In 1927, when the country was a British colony, a commission chaired by the Earl of Donoughmore was appointed to consider the revision of the Constitution. When the Donoughmore Commission visited the country, it was the Kandyan Sinhalese who proposed a federal arrangement, claiming that they were a separate 'nation'. They proposed a federation of three units corresponding to (1) the Sinhala-dominated areas of the maritime provinces that were conquered by the Portuguese in 1505 and that later came under Dutch and British rule, (2) the Kandyan Kingdom which was finally conquered by the British in 1815 and (3) the present Northern and Eastern provinces inhabited mainly by Tamils and Muslims. 'Ours is not a communal claim or a claim for the aggrandisement of a few: it is a claim of a nation to live its own life and realise its own destiny', the Kandyan National Assembly stated

9 Department of Census and Statistics of Sri Lanka, "Provisional Data from a $5 \%$ Sample of the Census of Population and Statistics, 2012," provided by email (census@statistics.gov. lk) to the author on 23 December 2013.

10 Solomon W. R. D. Bandaranaike, Ceylon Morning Leader, 19 May, 27 May, 2 June, 9 June, 23 June, and 30 June, 1926, reproduced in Power-sharing in Sri Lanka: Constitutional and Political Documents, 1926-2008, eds. Rohan Edrisinha et al. (Colombo: Centre for Policy Alternatives, 2008), 28-53.

11 Solomon W. R. D. Bandaranaike, Ceylon Morning Leader, 26 July, 1926, reproduced in Power-sharing in Sri Lanka: Constitutional and Political Documents, 1926-2008, eds. Rohan Edrisinha et al. (Colombo: Centre for Policy Alternatives, 2008), 5 o. 
in its memorandum. ${ }^{12}$ While sympathising with the concerns of the Kandyan Sinhalese, the Commission rejected the federal arrangement.

Under the 'Donoughmore' Constitution,13 which came into effect in 1931, communal representation was abolished. Franchise was granted to all men and women over 21 years old. The newly established State Council - the unicameral legislature - consisted of 61 members, 50 of whom were elected in territorial constituencies. The Chief Secretary, Legal Secretary and Financial Secretary were ex officio members but had no voting rights. Eight members were nominated by the Governor.

The Board of Ministers consisted of the three officials and seven Ceylonese Ministers who were the elected chairpersons of the respective executive committees. In the State Council elected at the 1931 elections, a Muslim and a Hill Country Tamil were represented in the Board of Ministers, the Tamils of the North having boycotted the elections. ${ }^{14}$ After the 1936 elections, ${ }^{15}$ which the Tamils contested, the Sinhalese majority in the State Council (apart from a few including N.M. Perera and Philip Gunawardena of the leftist Lanka Sama Samaja Party (LSSP)) manipulated the election of executive committees to ensure that all seven chairs went to the Sinhalese. This was probably the first lesson Tamils learned about who would control the state power once the country would become independent. The experience resulted in Tamils moving towards the demand for guaranteed representation.

The first political party in the country to propose Tamils be recognised as a distinct nation with the right to self-determination, including the right to form an independent state, was not a Tamil party but the Communist Party of Ceylon. ${ }^{16}$ The memorandum submitted in October 1944 on behalf of the Party to the Ceylon National Congress, of which it was a constituent, made reference

12 Donoughmore Commission, "Report of the Donoughmore Commission," (1928) ch. VI, referred to in Power-sharing in Sri Lanka: Constitutional and Political Documents, 192620o8, eds. Rohan Edrisinha et al. (Colombo: Centre for Policy Alternatives, 2008), 56.

13 Ceylon (State Council) Order in Council, 1931.

14 For election results see G.P.S. Harischandra De Silva, A Statistical Survey of Elections to the Legislatures of Sri Lanka, 1911-1977 (Colombo: Marga Institute, 1979), 91.

15 De Silva, A Statistical Survey, 91.

16 Resolution adopted by the Communist Party-controlled Ceylon Trade Union Federation on September 23, 1944, reproduced in Power-sharing in Sri Lanka: Constitutional and Political Documents, 1926-2008, eds. Rohan Edrisinha et al. (Colombo: Centre for Policy Alternatives, 2008), 111; Resolution passed at the Party's rally in Colombo on October 15, 1944, reproduced in Power-sharing in Sri Lanka: Constitutional and Political Documents, 1926-2008, eds. Rohan Edrisinha et al. (Colombo: Centre for Policy Alternatives, 2008), 113. 
to a 'federal Constitution' in its title but details of the proposed federal structure were not set out. ${ }^{17}$

When the Soulbury Commission on constitutional reform appointed by the British government visited Ceylon in 1944, no serious proposal was made to it by any organisation that the country should have a devolved structure, let alone a federal one. The Commission made no recommendations either for self-rule of any kind or for balanced representation. ${ }^{18}$

After the 1947 elections held a few months before independence under the British-given 'Soulbury' Constitution, ${ }^{19}$ the Tamil Congress (тС), then the only party of the Tamils, joined the conservative United National Party (UNP) to form a coalition government. Hill Country Tamils won six out of the 95 seats and collaborated with the Left to ensure the victory of several leftists. This was not to the liking of the leaders of the ruling UNP and when the Citizenship Act was enacted, a citizen was defined in such a manner that the vast majority of Hill Country Tamils were excluded. ${ }^{20}$ The law relating to elections was amended to provide that only citizens would be entitled to vote. ${ }^{21}$ Hundreds of thousands of Hill Country Tamils who voted at the 1947 elections as British subjects were thus disenfranchised.

The adoption of the new laws was a defining moment in Tamil politics, with serious political consequences. Tamil leaders in the government were unable to prevent the disenfranchisement of their Hill Country Tamil cousins. It was at this point that S.J.V. Chelvanayakam broke away to form the Federal Party (FP). The lesson was clear, at least to him: the Sinhalese majority wielded state

17 Edrisinha et al., Power-sharing in Sri Lanka, 121-125.

18 Commission on Constitutional Reform, Ceylon:Report of the Commission on Constitutional Reform (London: Cmd 6677, 1945).

19 Ceylon (Constitution) Order in Council, 1946.

20 Section 4, Ceylon Citizenship Act No. 18 of 1948:

(1) Subject to the other provisions of this Part, a person born in Ceylon before the appointed date shall have the status of a citizen of Ceylon by descent, if -

(a) his father was born in Ceylon, or

(b) his paternal grandfather and paternal great grandfather were born in Ceylon.

(2) Subject to the other provisions of this Part, a person born outside Ceylon before the appointed date shall have the status of a citizen of Ceylon by descent, if -

(a) his father and paternal grandfather were born in Ceylon, or

(b) his paternal grandfather and paternal great grandfather were born in Ceylon.

Section 4 of the Ceylon (Parliamentary Elections) Order-in-Council as amended by section 3 of the Ceylon (Parliamentary Elections) Amendment Act No.48 of 1949, https:// aceproject.org/regions-en/countries-and-territories/LK/case-studies/the-ceylonparliamentary-elecions-order-in-council.pdf, accessed August 12, 2020. 
power, and Tamils who thought they shared power in Colombo had in fact no say. For those who broke away, regional autonomy was the only salvation.

It is also important to note that the FP could only win two seats in the subsequent elections that followed in 1952. Chelvanayakam himself lost at Kankesanthurai, not to a candidate of the TC but to a candidate of the UNP. Despite the experiences of the late 1940s, the Tamils of the North and East decisively rejected federalism and mandated the TC to go back to Colombo and share power with the UNP. The year $195^{2}$ brought some changes in the South, as Bandaranaike, who had left the UNP in 1951 to form the SLFP, was able to become the Leader of Opposition.

In 1955, everything changed. Previously, the two main parties of the South, the UNP and the SLFP, had wanted Sinhala and Tamil to replace English as official languages. With another general election close at hand, both changed their position to 'Sinhala only'. This led to enhanced support for the FP and in the 1956 elections an SLFP-led coalition supported by the Left swept the South, while the FP swept the North and East. This time it was the TC's turn to be humiliated with two seats and it never recovered from the defeat. Sinhala was made the only official language in 1956. The Tamils and the Left opposed the move and Left leader Dr. Colvin R. De Silva prophetically stated - 'two languages - one country; one language - two countries' meaning that if both languages were not recognised as official languages at par, this might lead to a demand for separation. ${ }^{22}$ The warning was not heeded. The majority again demonstrated as to who had state power, which further aggravated the conflict.

Prime Minister Bandaranaike soon realised that accommodation was the only solution and, in July 1957, entered into an agreement with Chelvanayakam to set up Regional Councils in the North and East, with much less power than what provincial councils had under the present Constitution. The B-C Pact, ${ }^{23}$ as it came to be famously known, was fiercely opposed by extremist Buddhist monks and the UNP, and the Prime Minster was forced to abrogate it. The situation worsened, culminating in the 1958 communal riots, moving the two communities further apart.

After the elections of 1965 , the UNP was again forced to share power with the Tamil parties. Premier Dudley Senanayake entered into a pact with Chelvanayakam (the 'D-C Pact'). ${ }^{24}$ Senanayake agreed to concessions on the use of Tamil and limited devolution of power to District Councils. In regard to colonisation, he agreed that in future colonisation schemes in the North and

\footnotetext{
22 Hansard (Parliamentary Debates), Vol 24, Col 1917, 1956.

23 Edrisinha et al., Power-sharing in Sri Lanka, 220.

24 Edrisinha et al., Power-sharing in Sri Lanka, 228.
} 
East, priority would be given to the landless persons of the two provinces, followed by Tamils in the two provinces and then to people from other provinces, preference being given to Tamils. When a White Paper on District Councils was presented in Parliament in 1968, it was the SLFP's turn to oppose, joined by their coalition allies of the Left. The paper was withdrawn in the face of opposition and the FP soon left the government.

There were several other factors that worsened relations between the two communities in the 1950s and 196os. It was a period of worldwide nationalist and anti-imperialist agitation. A number of radical measures were taken, such as the takeover of foreign oil companies and assisted schools and agricultural reform. Tamil parties were not enthusiastic about such measures, even opposing many of them. They were very conservative on most issues, behaving like the 'cousins' of the UNP. Another factor was the secessionist movement in South India at the time. There was talk of a 'greater Tamil Nadu' that would include the North and East of Sri Lanka. ${ }^{25}$ This gave rise to deep suspicion and distrust. In addition, there was no shortage of communalists on either side, fanning hatred for political gain.

But with all these and the failure of the B-C Pact and the D-C Pact, there was still no serious talk of a separate state. In fact, even in 1970 the FP called upon the Tamil-speaking people in its election manifesto to vote against candidates who stood for the bifurcation of the country. This was an apparent reference to the first Tamil separatist party, the tiny 'Eelath Thamilar Otrumai Munnani' (етом) led by C. Suntharalingam.

1972 was a golden opportunity that was missed. The people of Sri Lanka were making their own Constitution through a Constituent Assembly and the entire membership of Parliament joined the process, including all the representatives of the Tamils. V. Dharmalingam, speaking for the F P during the discussion on the Basic Resolution on the unitary nature of the Constitution, pleaded for federalism or at least the recognition of the federal principle in a unitary form of government. Stating that the party was only asking the federal principle to be accepted, he suggested that, as an interim measure, the ruling coalition of the SLFP and the Left parties should implement what they had promised in the

\footnotetext{
25 Ganapathy Palanithurai K. Mohanasundaram, Dynamics of Tamil Nadu Politics in Sri Lankan Ethnicity (New Dehli: Northern Book Centre 2003), 44.
} 
election manifesto, namely that they would abolish Kachcheris ${ }^{26}$ and replace them with elected bodies. This was rejected by all parties of the South. Tamil representatives continued to participate in the Constituent Assembly but only until the Basic Resolution declaring Sinhala to be the only official language was passed. There was no dramatic walk out. In addition to Sri Lanka being declared a unitary state and Sinhala being recognised as the official language, the first Republican Constitution also gave Buddhism the foremost place. ${ }^{27}$

The Tamil MP s nevertheless took their oaths under the new Constitution. Later attempts at an understanding proved unsuccessful and the Tamil parties soon united under the banner of the Tamil United Front (TUF) that later became the Tamil United Liberation Front (TU LF). At the famous Vaddukoddai Conference held in 1976, the TULF embraced separatism and adopted a resolution for a separate state called 'Tamil Eelam' in the Northern and Eastern provinces that they claimed to be the historical homeland of the Tamils. ${ }^{28}$ During the 1977 elections, the TULF contested on a separatist platform and swept the Tamil areas.

The 1977 elections were significant for another reason. For the first time, one of the two major parties of the South, the UNP, acknowledged in its manifesto, 'A Programme of Action to Create a Just and Free Society', that Tamils had grievances and that the non-resolution of their problems had driven the Tamils towards separatism. It promised to set up a round table conference to address Tamil issues. Tamils outside the North and East voted overwhelmingly for the UNP. The UNP obtained an unprecedented five sixth majority but its share of the popular vote was $5^{0.9} \%$. However, no round table conference was ever organised.

The 1978 Constitution was another opportunity for a solution. But the UNP failed to respond and the Tamils refused to participate in making the Constitution. For the second time in Sri Lanka's history, a Constitution was adopted without the participation of the representatives of the Tamils, showing clearly that effective state power in Sri Lanka was with the Sinhalese. The

26 District administration headed by a government agent. Kachcheri is a Hindi word used for the Revenue Collector's Office during British rule. The system continued after independence. See S. S. Wickramanayake, "The Management of Official Records in Public Institutions in Sri Lanka: 1802-199o" (unpublished PhD diss., University of London, 1992), 28.

27 For a detailed discussion on the 1972 Constitution, see Jayampathy Wickramaratne, "The 1972 Constitution in Retrospect," in Towards Democratic Governance in Sri Lanka: A Constitutional Miscellany, ed. Jayampathy Wickramaratne (Rajagiriya: Institute for Constitutional Studies, 2014), 75-95.

Edrisinha et al., Power-sharing in Sri Lanka, 256. 
1978 Constitution entrenched the unitary nature of the Sri Lankan state, as well as the foremost place of Buddhism, and provided for a strong presidential executive. Entrenchment meant that any change needed a two-thirds majority in Parliament and approval by the people at a referendum.

Attacks on Tamils in 1983 forced thousands of Tamils to flee the island and the entire conflictual situation became internationalised. The TULF, which was for a compromise despite its separatist rhetoric, withdrew from Parliament and, not surprisingly, was soon upstaged by the numerous Tamil militant groups that had sprung up. A fully-blown separatist war followed.

Forced by these realities, President Jayewardene entered into an accord with India in 1987. This was followed by the 13th Amendment to the Constitution, which established provincial councils and provided for limited devolution. All Tamil militant groups except the Liberation Tigers of Tamil Eelam (LTTE) accepted the Indo-Lanka Accord in principle. Provincial councils with limited legislative and executive powers were set up. Tamil was also made an official language. However, literally every comma and full stop in the 13th Amendment had been used by the subsequent governments without exception to thwart the process of devolution..$^{29}$

The 13th Amendment established provincial councils with limited legislative and executive powers within a unitary state. There were three lists of subjects and functions: a reserved list, a provincial council list and a concurrent list. A provincial council had no power to make statutes on any matter set out in the reserved list. A provincial statute on a matter in the provincial council list made a pre-1987 parliamentary law on the same matter inoperative in the Province if the statute states in its long title that the statute was inconsistent with such law. However, the legislative power of a provincial council in regard to a matter in the provincial council list was not exclusive, as Parliament too could legislate on such matters. A parliamentary Bill on a provincial council matter had to be referred to all provincial councils for the expression of their views. If all agreed, Parliament could pass the Bill with a simple majority. If one or more provincial councils did not agree, and the Bill was passed by only a simple majority, then the Bill would become law applicable only to those

29 Jayampathy Wickramaratne, "Sri Lanka: Missed Opportunities and the Way Forward," in Towards Democratic Governance in Sri Lanka: A Constitutional Miscellany, ed. Jayampathy Wickramaratne (Rajagiriya: Institute for Constitutional Studies, 2014), 497-8. 
Provinces that agreed. But if the Bill was passed by a two-thirds majority, then the law would also apply in the Provinces that did not agree.

As for matters in the concurrent list, Parliament had to consult provincial councils before it took up a Bill and, conversely, the same applied to a provincial council. In the event of inconsistency, the parliamentary law would prevail. However, a provincial council statute on such a matter would make a pre-1987 law on the subject inoperative unless Parliament decided otherwise.

A significant feature of the reserved list is its first item: national policy on all subjects and functions. This is a provision that was abused by the Centre under successive governments. It is reasonable to expect the provision to mean that Parliament may lay down national policy even relating to a matter in the Provincial list or the concurrent list by a simple majority and provincial councils should abide by such national policy in making statutes. In view of the express provision contained in Article $154 \mathrm{G}$ (3) of the Constitution of 1978 that a parliamentary law relating to a matter on the provincial list would apply in a Province only if that Province had adopted the law by a two-thirds majority, there can be little doubt that, on the pretext of establishing national policy, Parliament could not legislate by a simple majority on a matter from the provincial council list without the consent of the provincial council concerned. In other words, national policy on matters set out in the provincial council list and the concurrent list would be in the nature of framework legislation to which provincial councils should conform.

To take one example, under item 8 of the provincial council list, the regulation of road passenger carriage services and carriage of goods by motor vehicles within the Province and the provision of intra-provincial road transport services were provincial subjects. This clearly permitted a provincial council to set up its own transport services. The Colombo government, however, prohibited provincial councils from providing omnibus services, claiming to declare 'government policy' through the National Transport Commission Act of 1991. Although it is clear from a reading of the 13th Amendment that national policy could only be laid down by an Act of Parliament, successive governments purportedly laid down such policy by Cabinet decisions and ministry circulars.

In Kamalawathie v. Provincial Public Service Commission of the NorthWestern Province, ${ }^{30}$ the petitioners alleged in the Supreme Court that a circular giving a national teacher transfer policy declared by the Cabinet of Ministers as national policy had not been followed by a provincial Public

30 Kamalawathie v. Provincial Public Service Commission of the North-Western Province [2001] 1 Sri LR 1. 
Service Commission. Judge Mark Fernando, with Judge Wadugodapitiya and Judge Ismail agreeing, held that the circular sets out national policy on an important aspect of education. 'While powers in respect of education have been devolved to Provincial Councils, those powers must be exercised in conformity with national policy. Once national policy has been duly formulated in respect of any subject, there cannot be any conflicting provincial policy on the same subject.' ${ }^{31}$

It is submitted that the Supreme Court erred in holding that the Cabinet of Ministers' decision constituted a duly formulated national policy binding on the provincial councils. The scheme of the 13th Amendment allows no interpretation other than that national policy can only be determined by law.

In 1995, the Gunawardena Committee, appointed to study the functioning of provincial councils, had the following to say on how the national policy provision had been misused:

There has been a tendency on the part of Government Ministries to interpret National Policy in operational terms, thereby extending their areas of administrative action in respect of provincial subjects. [...] National Policy being a reserved function brings into effect a role differentiation between the Government and the Province. Thus, whereas the Government performs a directive role the Province is relegated to an implementational role. Hence there is a tendency on the part of the Government to give policy directives, marginalizing the Province from the decision-making process. This leaves only a residual role which is largely operational. The tendency to view the Province in operational terms is reinforced by the nature and scope of Government-Province relations currently in place. It is a negation of the power sharing basis of devolution and does not constitute a relation for establishing a partnership between the Government and the Provinces. ${ }^{32}$

Under Article $154 \mathrm{C}$ of the Constitution, the executive power of a provincial council extends to matters with respect to which a provincial council has power to make statutes, namely matters in the provincial council list and the concurrent list. However, for provincial authorities to exercise executive

31 Kamalawathie v. Provincial Public Service Commission of the North-Western Province [2001] 1 Sri LR 1, 5 (emphasis added).

32 Committee to Study the Operation of Provincial Councils in Sri Lanka, "Provincial Councils: Operational Experience of Devolution," Report of the Committee to study the Operation of Provincial Councils in Sri Lanka (1996, unpublished), 52. 
power, they need statutory authority. In 1987, when the legal basis for the provincial councils was established, there were at least 300 pieces of legislation relating to matters included in the provincial council list and the concurrent list. References in such laws to the minister or a particular public officer could not be construed as references to the Governor, provincial minister or the corresponding provincial public officer unless the 13th Amendment contained an express provision to that effect. Provincial councils were thus faced with the impossible task of passing statutes corresponding to all such laws if they were to exercise executive power. They did not have their own draftsmen and had to rely on the central state for this as well. In the absence of a statute, the central state would continue to exercise executive power in respect to the subject in question.

As a result, provincial councils pressed the government to enact parliamentary legislation providing that all references in existing law with respect to matters included in the provincial and concurrent lists be construed as references to the corresponding provincial authorities. The government reluctantly agreed to make such a provision, which, however, only applies to the provincial list and also keeps the powers of the Centre intact. The Provincial Councils (Consequential Provisions) Act No. 12 of 1989 was accordingly passed. There remained an estimated 200 laws in respect to matters set out in the concurrent list that were not covered by the Act. Even to this day, only a few such statutes have been enacted by the various provincial councils, mainly due to lack of their own draftsmen, but also due to frustration resulting from the Centre's lack of support. The central government has not moved to prepare model statutes that could be used by provincial councils, unlike in some other countries. In the absence of their own statutes, provincial authorities are unable to exercise executive power, notwithstanding Article $154 \mathrm{C}$ of the Constitution.

Problems cropped up even regarding matters set out clearly in the provincial list. A pre-1987 parliamentary law on such a matter would be inoperative in a Province only if a statute was made. Although provincial authorities were able to exercise powers under a pre-1987 law to which the provincial councils (Consequential Provisions) Act applies, central authorities were also able to exercise powers if they wished to do so, unless and until a provincial statute was made. What happened in the case of the Ratnapura and Kegalle Base Hospitals that were administered by the Sabaragamuwa provincial council is illustrative: the Centre moved to take over the administration of the two hospitals in 1994 and the Attorney General advised the Centre that in the absence of a provincial statute which provides for the administration of the two hospitals, 'the control of these two hospitals legally remains with the Ministry of 
Health. ${ }^{33}$ On being asked for advice on whether the minister at the Centre could exercise the power of supervision over local authorities if there was no provincial statute on the subject, the Attorney General stated: 'It should also be noted that the Provincial Councils (Consequential Provisions) Act does not take away from the Minister of the central government the powers which he has under any Act of Parliament, which can continue to be exercised by him as well. ${ }^{34}$ Clearly, the Centre was making use of the difficulties faced by provincial councils in making their own statutes to encroach on areas devolved on the provinces. With regard to interference by the Centre, the Gunawardena Committee stated:

Most Government Ministries continue to conduct their operations on a pre-devolution basis. Thus Government Ministries routinely address guidelines and circular instructions direct to the respective provincial heads of departments by-passing the provincial Ministry. Further, there has been no restructuring at the centre in terms of roles and functions in the context of devolution. It would appear that there has been a failure on the part of most Government Ministries to formulate national policies in their sectoral subjects in partnership with provincial councils. ${ }^{35}$

It is instructive to examine in detail one significant case of a clash between the centre and provinces. The Agrarian Services (Amendment) Bill of 1991 sought to amend several sections of the original act that dealt with matters relating to landlords and tenant cultivators. The Bill was challenged in the Supreme Court on the ground that it dealt with matters set out in the provincial council list as well as the concurrent list and should have been referred to the provincial councils. The Bill made no reference, in the preamble or elsewhere, to national policy being made. The Centre did not claim even in Court that the Bill sought to lay down national policy. However, the Court held that '[it] is sufficient for present purposes that the matters dealt with in the Bill are all matters of national policy in regard to the rights and liabilities of owners and tenantcultivators, and thus fall within [the reserved list] ${ }^{36}$ How national policy could

33 Committee to Study the Operation of Provincial Councils in Sri Lanka, Provincial Councils, 57 .

34 Committee to Study the Operation of Provincial Councils in Sri Lanka, Provincial Councils, 55 .

35 Committee to Study the Operation of Provincial Councils in Sri Lanka, Provincial Councils, $7^{-8}$.

36 Decisions of the Supreme Court on Parliamentary Bills (1991-2003), Vol. viI, 9. 
be laid down by amending an existing law in a matter of the provincial council was not explained.

With the establishment of provincial councils in 1988, agrarian services was considered a provincial subject and the councils had their own Departments of Agrarian Services; matters relating to landlords and tenant cultivators were handled by these departments. After the Supreme Court's aforesaid determination, an Additional Solicitor General informed the Centre that in view of the decision of the Supreme Court, the matters dealt with in the Bill were all matters of national policy in regard to the rights and liabilities of owners and tenant cultivators and thus fell within the reserved list; the Centre could proceed 'on the basis that Agrarian Services is not a devolved subject.' ${ }^{37}$ Soon, the Centre took over the provincial departments. The advice was clearly wrong. Even if the Supreme Court was correct in saying that the matters covered by the Bill were all matters of national policy it does not follow that Agrarian Services necessarily be a subject in the reserved list. When national policy is declared in respect of a subject in either the provincial list or the concurrent list, this does not shift the subject to the reserved list.

In 2003, in Madduma Bandav. Assistant Commissioner of Agrarian Services, ${ }^{38}$ the Supreme Court held that matters relating to tenant cultivators be included in the provincial list. Commenting on the earlier determination, the Court took the view that it would not be correct to say that the matters dealt with by the Bill were all matters of national policy. The judgment was certainly devolutionfriendly. However, despite the clarification, the subject of agrarian services was not returned to the provincial councils. ${ }^{39}$

\section{Later Attempts for a Constitutional Settlement}

Chandrika Bandaranaike Kumaratunga became President in 1994. The Sri Lanka Freedom Party (SLFP) had vigorously opposed the 13th Amendment under the leadership of her mother, Sirimavo Bandaranaike, the world's first

37 Committee to Study the Operation of Provincial Councils in Sri Lanka, Provincial Councils, 52 .

38 Madduma Banda v. Assistant Commissioner of Agrarian Services [2003] 2 Sri LR 80.

39 For a fuller discussion on the working of Provincial councils see Lakshman Marasinghe and Jayampathy Wickramaratne, 13th Amendment: Essays on Practice (Pannipitiya: Stamford Lake, 2010); Ranjith Amarasinghe et al., Thirty Years of Devolution: An Evaluation of the Working of Provincial councils in Sri Lanka (Rajagiriya: Institute for Constitutional Studies, 2019). 
woman Prime Minister. However, under Kumaratunga's leadership, the SLFP adopted a pro-devolution platform. Between 1994 and 20oo, she led a dynamic campaign for a strong power-sharing arrangement as a solution to Sri Lanka's ethnic crisis. Surveys commissioned by her showed that while only $23 \%$ of the Sinhala people were for a negotiated settlement in 1996, numbers had increased to $68 \%$ by 1999. In August 2000, after several months of discussions with the UNP, the Kumaratunga Administration presented the Constitution of the Republic of Sri Lanka Bill. However, with the dissolution of Parliament for General Elections only a few weeks away, the UNP withdrew its agreement to support the Bill. The Bill was debated in Parliament but not put to a vote, as the necessary two-thirds majority was not forthcoming.

The 2000 Constitution Bill proposed a non-unitary framework. Rather than using a label to describe the nature of the State, the Bill stated: 'The Republic of Sri Lanka is one, free, sovereign and independent State consisting of the institutions of the Centre and of the Regions which shall exercise power as laid down in the Constitution' (Article 1). A clear-cut division of powers between the Centre and the Regions was proposed. The legislative power of the Regions would be exclusive and there would be no concurrent list. The subjects on which national policy could be made by the Central Legislature would be restricted.

At the parliamentary elections held in October 200o, the People's Alliance (PA) won with a slim majority which it soon lost due to defections. At the elections held in December 2001, the UNP secured a majority and Ranil Wickremasinghe formed a government under the Kumaratunga presidency. A ceasefire with the LTTE was agreed to and peace talks were held. The government and the LTTE agreed in Oslo in December 2002 to 'explore' a federal solution.

With Kumaratunga who introduced the 2000 Constitution Bill as President and Wickremasinghe as Premier, this was another opportunity for a Southern consensus, but Wickremasinghe did not get Kumaratunga on board the peace process, instead attempting to deal with her through intermediaries. This was not to the liking of the latter who was constitutionally empowered to 'declare war and peace' as President. While Wickremasinghe may have suspected that Kumaratunga would do a kind of tit for his tat of 2000 , recent defectors from the SLFP to the UNP who held important positions in the Wickremasinghe administration are also said to have sabotaged any possibility of such rapprochement.

The Wickremasinghe government offered an interim administration dominated by the LTTE in the North-East ${ }^{40}$ but the LTTE made a counter demand in October 2003 for an Interim Self-Governing Authority (ISGA) with 'plenary 
power for the governance of the North-East' including powers in relation to resettlement, rehabilitation, reconstruction, development, raising revenue including imposition of taxes, revenue, levies and duties, law and order, and over land. It demanded that all government expenditures in or for the NorthEast should be subject to the control of the ISGA. According to the proposal, the ISGA would have had powers to borrow internally and externally, provide guarantees and indemnities, receive aid directly, and engage in or regulate internal and external trade. It would also have had direction and control over any and all administrative structures and personnel in the North-East and the power to alienate and determine the appropriate use of all land in the North-East that was not privately owned. Land occupied by Sri Lankan armed forces would have had to be immediately vacated and restored to the possession of the previous owners. The ISGA would have had control over the marine and offshore resources of the adjacent seas and the power to regulate access thereto. It would also have had control over the natural resources in the region. ${ }^{41}$ However, some of the proposed powers of the ISGA would not have been possible under the existing unitary Constitution. Granting 'plenary power for the governance of the North-East' would have been permissible only in a confederal setting. While the people may have ultimately supported a federal structure as a part of a comprehensive peace agreement that would lead to the end of violence, the ISGA would have been hard to sell as an interim arrangement. Nevertheless, the ISGA proposal could have been a basis for further talks.

On 4 November 2003, a few days after the ISGA was proposed, Kumaratunga used her presidential powers to take over the ministries of defence, interior and media. Without the key Ministry of Defence, Wickremasinghe now had very few remaining options. The peace process was all but dead. On 7 February 2004 Parliament was dissolved. In the ensuing elections, the United People's Freedom Front (UPFA), led by Kumaratunga and joined by Janatha Vimukthi Peramuna (JVP), a left-wing party opposed to devolution, won a majority of seats. Was the LTTE sincere in agreeing to a ceasefire and talks about a political solution? Many observers take the view that it was only a tactical move and that the LTTE's commitment was to a separate state and nothing short of it. It was aware of the difficulties of the Southern polity to forge a consensus on a political solution. The LTTE appears to have been bent on gaining control of an interim administration that would have 'gelled' with time and with no constitutional solution. Its chief negotiator himself later disowned the LTTE's willingness to explore a solution to the Tamil problem within a federal framework. 
The LTTE's hard-line position in turn helped hardliners within the Sinhala majority. Mahinda Rajapakse ascended the presidency in 2005 with the support of Sinhala hardliners. Interestingly, the LTTE preferred a hardliner to a moderate and enforced a boycott of the poll in the areas it controlled, denying Wickremasinghe, who offered a high degree of devolution, several hundred thousand decisive votes. This only confirms that the LTTE was never interested in a political settlement and overestimated itself as a military force. Within four years, Rajapakse's military machine completely decimated the LTTE.

The LTTE also misread the post-9/11 international situation. Most international actors helped Rajapakse to defeat the LTTE, directly or indirectly, although some were not happy with what was happening during the last stages of the war. India also helped; notwithstanding the large Tamil population in Tamil Nadu, most of whom did not support a separate state but had great sympathy for Sri Lankan Tamils. The ruling Congress had another reason to see the end of the LTTE; the latter had assassinated Rajiv Gandhi, a former Indian Prime Minister and Congress leader. Gandhi's killing was another huge blunder on the part of the LTTE and its arrogant leader Prabhakaran.

While the war against the LTTE was on, President Rajapakse summoned an All Party Conference (APC) which in turn appointed an All Party Representative Committee (APRC) to make specific proposals for a constitutional settlement. He also appointed a 17-member panel of experts to assist the APRC. The panel of experts was divided. Eleven experts who included Sinhalese, Tamils and a Muslim proposed a strong power-sharing arrangement, ${ }^{42}$ four Sinhalese experts proposed minimal devolution while two others presented their own reports.

The so-called 'majority report' recommended a double-pronged approach: extensive devolution on the one hand, so that communities could exercise their power and develop their own territories within the respective areas, and power-sharing at the centre on the other hand, which would integrate the various communities into the body and strengthen national integration. In other words, a clear-cut division of powers between the centre and the provinces was proposed. Subjects such as defence, national security, foreign affairs, immigration, communications, national transportation, international trade, maritime zones and shipping, which are necessary to ensure the

42 Edrisinha et al., Power-sharing in Sri Lanka, 784. The author of this chapter was a signatory to the 'majority report'. 
sovereignty, territorial integrity and economic unity of Sri Lanka, would be reserved for the Centre, while other subjects would be devolved. The majority also recommended avoiding the use of distinctive expressions such as unitary, federal, or union of regions and describing the state in the Constitution as consisting of 'institutions of the Centre and of the Provinces which shall exercise power in the manner provided for in the Constitution', similar to the phrase used in the 2000 Constitution Bill. ${ }^{43}$ The multi-ethnic, multi-lingual, multireligious and multi-cultural character of Sri Lankan society was to be recognised, whilst safeguarding the unity and territorial integrity of the Republic. Another significant proposal was that the 'Peoples' of Sri Lanka were to be described in the Constitution as being composed of 'the constituent peoples of Sri Lanka' and that every constituent people would have the right, inter alia, to its due share of state power. This would be without in any way weakening the common Sri Lankan identity.

The majority report was welcomed by moderates among the majority Sinhalese and overwhelmingly by Tamils, Muslims and Hill Country Tamils. Not surprisingly, the LTTE chose not to comment on the contents, instead questioning the right of the Tamil experts to represent the community. The APRC process dragged on for three years. Sinhala nationalist parties withdrew at various stages, but the SLFP, the main party in the government, remained. Although no report was officially published, APRC Chairman Vitarana presented a summary of its proposals to the President in 20og. The proposals fell short of what the 'majority report' had recommended. Yet, extensive devolution within a unitary state was proposed with power-sharing at the centre and the proposals could form the basis for talks. Interestingly, the Presidential Secretariat denied that it had a copy of the proposals while Vitarana reiterated that he had submitted a summary to the President. Subsequently, Ramaiah Yogarajan and Nizam Kariapper, who represented the Ceylon Workers Congress and the Sri Lanka Muslim Congress respectively, released a summary of the decisions based on the minutes of the $\mathrm{APRC}^{44}$ and Vitarana conceded that it was an accurate summary.

Dr. Colin Irwin of the University of Liverpool, with vast experience in conducting opinion polls in conflict zones including Northern Ireland, Kashmir,

43 Clause 1 of the Constitution of the Republic of Sri Lanka Bill, 200o, https://www.peaceagreements.org/viewmasterdocument/1007, accessed 30 January 2021.

44 Ramaiah Yogarajan and Nizam Kariapper, eds., "Proposals made by the All Party Representatives Committee to form the basis of a new Constitution," www.groundviews.org/wp-content/uploads/July-2o-APRC-Final-Report.pdf?46986d, accessed on 8 May 2013. 
the former Yugoslavia and Sudan, tested the preliminary proposals of the APRC against public opinion in March 2009, just three months before the end of the war. A year later, in March 2010, nine months after the end of the war, the same proposals were tested again, but with a larger sample that included people in the Northern Province. ${ }^{45} \mathrm{~A}$ summary of the APRC proposals as they existed in February 2009 was listed as a series of 14 'show cards'. Those interviewed were asked what they thought of each item on a given card. Was it 'essential', 'desirable', 'acceptable', 'tolerable' or 'unacceptable'? They were then asked for their views on the 'package' as a whole, that is to say, whether they would support such a 'package' and under what circumstances.

Irwin reported that the percentages of Tamils, Muslims and Hill Country Tamils to whom the reform proposals taken together as a 'package' were 'essential', 'desirable' or 'acceptable' were as follows (Table 6.1):

TABLE 6.1 Support for reform proposals among Tamils,

Muslims and Hill Country Tamils

\begin{tabular}{llll}
\hline & Tamils & Muslims & $\begin{array}{l}\text { Hill Country } \\
\text { Tamils }\end{array}$ \\
\hline 2009 & $82 \%$ & $85 \%$ & $90 \%$ \\
2010 & $83 \%$ & $88 \%$ & $90 \%$ \\
\hline
\end{tabular}

The above figures were not in any way surprising. What was surprising to many was the response of the Sinhalese (Table 6.2):

TABLE 6.2 Support for reform proposals among Sinhalese

$200959 \%$ (essential $-13 \%$, desirable $-21 \%$, acceptable $-25 \%)$

$2010 \quad 80 \%$ (essential $-20 \%$, desirable $-38 \%$, acceptable $-22 \%$ )

Contrary to the myth propagated by opponents of devolution that the Sinhalese did not support devolution, $59 \%$ of the respondents considered the

45 Colin Irwin, “'War and Peace' and the APRC Proposals," peacepolls.org (2010), www.peacepolls.org/peacepolls/documents/ool173.pdf, accessed on October 15, 2013. 
APRC proposals at least 'acceptable' three months before the end of the war in May 2009. One year later, the figure had risen to as much as $80 \%$.

The Lessons Learnt and Reconciliation Commission (LLRC), appointed by the President in May 2010 and headed by a former Attorney-General, submitted its report in November 2011. ${ }^{46}$ The Commission made a number of farreaching recommendations. The LLRC report was well received both within Sri Lanka and abroad. In regard to a political solution, the LLRC stated that a political solution was imperative to address the causes of the conflict: 'Everybody speaks about it, though there is no agreement about the diagnosis and the prescription,' the Commission lamented. It said that the government had to take the initiative to have a serious and structured dialogue with all political parties, in particular those representing the minorities, based on a proposal containing the government's own thinking on the form and content of the dialogue process envisaged. That dialogue would have to take place at a high political level and with an adequate technical backstop. The onus of initiating and carrying forward a dialogue was thus placed squarely on the shoulders of the government. The LLRC also stated that any devolution or power-sharing mechanism would have to be implemented within the broad framework of a sovereign, politically independent and multi-ethnic Sri Lankan state. While the distribution of meaningful powers to the periphery was essential, there were powers that formed the core responsibilities of the state and that could not be so devolved - and therefore had to be retained and exercised by the government at the Centre. It was also important to ensure that any power-sharing arrangement had inbuilt mechanisms that would effectively address and discourage secessionist tendencies and safeguard the sovereignty and integrity of the state.

The LLRC's views were not new, yet they were of significance coming from a commission appointed by the government. The Rajapakse Administration repeatedly made promises to the international community and to neighbouring India that it was committed to a political solution, ${ }^{47}$ but no meaningful steps were taken towards that end. On the contrary, efforts were made to dilute the 13th Amendment. Such moves were not successful due to the Indian factor as well as opposition from within the ruling coalition. Although another

46 Commission on Inquiry on Lessons Learnt and Reconciliation, "Report of the Commission on Inquiry on Lessons Learnt and Reconciliation" (November 2011), http://slembassyusa. org/downloads/LLRC-REPORT.pdf, accessed on 8 May 2013.

47 Dianne Silva, "Full Implementation of 13th Amendment Plus, MR Tells Krishna," Daily Mirror, 17 January 2012, http://www.dailymirror.lk/16141/full-implementation-of-13thamendment-president-tells-krishna-, accessed on 24 june 2019. 
Parliamentary Select Committee was appointed, the Tamil parties and the UNP held back and declared that the government had to first make known its position on a political solution.

In September 2013, the moderate Tamil Nationalist Alliance (TNA) won 30 out of 38 seats at the first elections to the Northern provincial council, making the new Council the only one controlled by the opposition. C.V. Wigneswaran, a former Judge of the Supreme Court, became the Chief Minister, raising hopes of pro-devolution forces in the country. But he soon joined Tamil hardliners and was accused of doing little for the cause of devolution.

The reports of the APRC, LLRC and the Panel of Experts appointed by him notwithstanding, Rajapakse did nothing towards settling the conflict. Clearly, he was accused of only paying lip service. Having passed the 18th Amendment to the Constitution to remove the few limitations on the executive presidency and the two-term limit, Rajapakse called elections in 2014 two years in advance. At the Presidential election held on 8 January 2015, Rajapakse lost to Maithripala Sirisena, the General Secretary of his own party (SLFP) who defected to become the 'common candidate' of the opposition. The main plank of Sirisena's platform was the abolition of the executive presidency and a return to a parliamentary form of government. Tamils, Muslims and Hill Country Tamils voted overwhelmingly for him. The Tamil Nationalist Alliance stated publicly that while it did not extract any promises from Sirisena on the resolution of the ethnic conflict, it had the fullest confidence in him that he would usher in a constitutional settlement. Wickremasinghe, the leader of the UNP, was appointed Prime Minister. After his victory, Sirisena was invited by the SLFP to lead the party in place of Rajapakse.

At the general elections that followed in August 2015, the United National Front for Good Governance (UNFGG) led by Wickremasinghe won 106 out of 225 seats and Wickremasinghe was again appointed Prime Minister. The SLFP-led United People's Freedom Front (UPFA) won ninety-six seats and the Tamil Nationalist Alliance won sixteen. The majority of Members of Parliament belonging to the UPFA supported Rajapakse and sat in the Opposition benches, calling themselves the Joint Opposition while over thirty supported Sirisena and sat in the government benches. A major problem for Sirisena was that most of the Members who supported him supported Rajapakse on 8 January 2015 and did not identify themselves with the wishes of the masses who voted for Sirisena as the 'common candidate'. Their support for the constitutional reform process was at best half-hearted. Some of them later joined the Opposition and finally, the SLFP too left the government. 
While power-sharing through devolution to the periphery has been a successful tool in meeting secessionist challenges in many countries, a large number of those who opposed devolution in Sri Lanka have spread fear among the people that devolution would lead to the secession of the Northern and Eastern Provinces. However, the author is not aware of a single example in which the governing authority of a regional unit has used the powers devolved on it for secession. If a majority in Scotland decided to leave the United Kingdom, secession would be despite devolution, not because of devolution. The same would apply in case of a secession of Catalonia from Spain. However, if there are people who genuinely believe that powers devolved may be used to secede, it is best that such fears be assuaged. Historical reasons too sometimes play a part: even an offer of the right to secede could not lure Eritrea to stay with Ethiopia, for example.

The description of the Sri Lankan state as 'unitary' in 1972 and its subsequent entrenchment have impeded efforts at meaningful power-sharing. In constitutional theory, a unitary state is one in which the central government is supreme and administrative divisions exercise only powers that the central government delegates. In short, there is only one ultimate source of state power. For many Sri Lankans, however, 'unitary' means 'oneness' or 'one country'. The Sinhala word for 'unitary' is 'ekeeya' and 'eka' is 'one'. Thus, changing the unitary nature of the state is seen by some as 'dividing' the country.

The issue has been complicated with the Federal Party's Tamil name being 'Illankai Thamil Arasu Kachchi' which translates as 'Lanka Tamil State Party'. While opponents say that the Tamil name makes it clear that the ultimate aim of the party is a separate state, party leaders deny this and point out that in India, the subnational unit is called a 'state'. They say that when the party was formed, it took inspiration from India and all it wished to achieve was a 'Tamilmajority state' as in quasi-federal India.

Article $157 \mathrm{~A}(4)$ of the Sri Lankan Constitution states that " $[w]$ here any political party or other association or organization has as one of its aims or objects the establishment of a separate State within the territory of Sri Lanka, any person may make an application to the Supreme Court for a declaration that such political party or other association or organization has as one of its aims or objects the establishment of a separate State within the territory of Sri Lanka'. One of the consequences of such a declaration is that the political party or other association or organisation concerned shall be deemed to be proscribed for all purposes, and that any member of the political party 
or other association or organisation who is a Member of Parliament shall be deemed to have vacated their seat in Parliament with effect from the date of such declaration. ${ }^{48}$

In Chandrasoma v. Senathirajah, ${ }^{49}$ the petitioner sought a declaration that the Federal Party was a political party which had as its aims and objects the establishment of a separate State within the territory of Sri Lanka. The Supreme Court, having reviewed the party constitution and affidavits submitted by party officials, found that the Federal Party supported or advocated the establishment of a federal State within a united Sri Lanka. It did not, however, support, espouse, promote, finance, encourage or advocate the establishment of a separate State within the territory of Sri Lanka. The Court observed that advocating a federal form of government within the existing state could not be considered as advocating separatism.

Federalism had become a 'dirty word' in Sri Lankan politics and much heat was generated when the People's Alliance Government's 1997 proposals sought to describe the state as a 'union of regions'. Constitution drafters therefore needed to be pragmatic and avoid language that could lead to confusion. This is precisely what the PA government was advised to do and accordingly, the 20oo Constitution Bill stated in proposed Article 1: "The Republic of Sri Lanka is one, free, sovereign and independent state consisting of the institutions of the Centre and of the Regions which shall exercise power as laid down in the Constitution.' As the majority report of the Panel of Experts later stated in agreement, the use of distinctive expressions, such as unitary, federal, union of regions/provinces was to be avoided in describing the nature of the state.

The Public Representations Committee on Constitutional Reform appointed by the government in 2016 to receive public representations on constitutional reform to support the present constitutional reform process stated in its report:

With regard to the nature of the State, there were many views expressed by people ranging from a federal to a unitary State, secular to non-secular with other in-between options between a federal and unitary State as well. Given the fact that the ideal of a federal State has been long mooted by Tamil politicians many of the representations from the Northern Province and also from the Tamil community in the Eastern Province, articulated the desire for a federal State. It should also be noted however, that some individuals and groups from other parts of the country and

48 Article 157A (5) of the Constitution.

49 Chandrasoma v. Senathirajah, sC Spl. o3/2014, SCM 04.08.2017. 
from among the other communities also proposed a federal State or a power sharing mechanism as the best means of responding to the grievances of the Tamil people.

At the same time, there were many submissions from other parts of the country that strongly expressed the desire for a unitary State. What is clear is that the idea of a federal State is strongly linked to the notion of separatism by those who opposed federalism. At the same time, they also associate a unitary State with an indivisible country. On the other hand, a unitary State is viewed by those who favour greater devolution and a federal structure as a continuation of an undemocratic, centralized form of State control. The fear of a federal State especially among the Sinhalese, arises from the idea that a federal State will eventually lead to separation. Fears regarding a unitary State are based on the idea that it will lead to rule of the majority and the centralization of power. ${ }^{50}$

Does the recognition of a State as a 'unitary state' ensure its territorial integrity and indivisibility? This has been a major issue raised in the current discourse. The Steering Committee stated in its report:

The President whilst speaking on the Resolution to set up the Constitutional Assembly, stated that whilst people in the south were fearful of the word 'federal', people in the north were fearful of the word 'unitary.' A constitution is not a document that people should fear. The classical definition of the English term 'unitary state' has undergone change. In the United Kingdom, it is now possible for Northern Ireland and Scotland to move away from the union. Therefore, the English term 'Unitary State' will not be appropriate for Sri Lanka. The Sinhala term 'aekiya raajyaya' best describes an undivided and indivisible country. The Tamil language equivalent of this is 'orumiththa nadu'.51

The United Kingdom referred to here, with only local government institutions below the national government, was long regarded as a proto-typical unitary state. According to the British doctrine of parliamentary sovereignty, Parliament is the supreme legal authority in the United Kingdom which can make or repeal any law. Any law can be changed by a future parliament and

50 Public Representations Committee on Constitutional Reform, Report on Public Representations on Constitutional Reform (Colombo: Public Representations Committee on Constitutional Reform, 2016), 20. 
courts cannot overrule parliamentary legislation. The United Kingdom does not have a written Constitution against which the validity of laws passed by Parliament could be tested, but unwritten constitutional principles which are respected. It also has many laws of constitutional importance. If a 'unitary state' means a state whose territorial integrity is assured, then the United Kingdom was not and is not a unitary state. The Parliament of the United Kingdom of Great Britain and Ireland passed the Irish Free State Constitution Act ${ }^{52}$ in 1922 to allow Ireland (minus Northern Ireland) to become a dominion and with the exit of Ireland the remainder became the United Kingdom of Great Britain and Northern Ireland. Ireland became a Republic in 1949 and left the British Commonwealth. ${ }^{53}$

In an effort to end the violence in Northern Ireland, the governments of the United Kingdom and the Republic of Ireland agreed on Good Friday in 1998 that it was for the majority of the people of Northern Ireland to decide whether they preferred to continue to support the Union with Great Britain or a sovereign united Ireland. To put the 'Good Friday Agreement' into legal effect, the British Parliament passed the Northern Ireland Act 1998, which also repealed the Government of Ireland Act 1920. When a referendum on Scottish independence was to be held in Scotland, the UK government drafted an Order in Council granting the Scottish Parliament the necessary powers to hold an independence referendum. The draft Order was approved by resolutions of both Houses of Parliament of the United Kingdom. Under the powers thus temporarily transferred from Westminster, the Scottish Independence Referendum Act 2013 was passed by the Scottish Parliament. At the referendum held in 2014, a majority decided not to leave the United Kingdom. Thus, the UK Parliament itself provided for the secession of Ireland. It recognised that a majority of the people of Northern Ireland ought to be able to decide on the issue of secession from the UK and unification with Ireland. It also recognised that a majority of Scots ought to be able to decide if Scotland should leave the United Kingdom. The above shows that describing a state as 'unitary' is not, in and of itself, a barrier against secession.

Proponents of devolution argue that describing the Sri Lankan State as 'unitary' in the English version of the Constitution is undesirable for another reason: namely that there exists a certain 'unitary mindset' in Sri Lanka according to which any issue that arises between the Centre and a Province is decided

\footnotetext{
52 Constitution of the Irish Free State (Saorstát Eireann) Act, 1922, http://www.irishstatutebook.ie/eli/1922/act/1/enacted/en/print.html, accessed 12 August 2020. 
in favour of the Centre. They argue that while 'unitary' in the classical sense means that powers devolved may be withdrawn by the Centre through constitutional amendment, there have been many instances of legislative, executive and even judicial power which in turn undermine devolution. Sadly, successive governments have used every conceivable provision to frustrate devolution. The situation has been worsened due to the lack of a devolution-friendly administration. ${ }^{54}$ Examples of such a 'unitary mindset' are available in abundance and several were given in detail earlier in this chapter.

Taking into consideration the fears of pro-devolution forces as well as those who fear that devolution has the potential to lead to secession, the Steering Committee proposed to include the following in the new Constitution:

- In Sri Lanka, sovereignty will vest with the people and shall be inalienable and indivisible.

- Sri Lanka should remain one undivided and indivisible country.

- There shall be specific provisions included in the Constitution to prevent secession (division of the country).

- Maximum devolution should be granted.

- The Constitution shall be the Supreme Law of Sri Lanka.

- The power to amend the Constitution, or to repeal and replace the Constitution, shall remain with the Parliament and the People of Sri Lanka (where applicable), in the manner set out in the Constitution. ${ }^{55}$

In consequence, the following formulation was proposed for consideration:

Sri Lanka (Ceylon) is a free, sovereign and independent Republic which is an aekiya rajyaya /orumiththa nadu, consisting of the institutions of the Centre and of the Provinces which shall exercise power as laid down in the Constitution.

In this Article aekiya rajyaya / orumiththa nadu means a State which is undivided and indivisible, and in which the power to amend the Constitution, or to repeal and replace the Constitution, shall remain with the Parliament and the People of Sri Lanka as provided in this Constitution.

54 For the constitutional framework of devolution and important legal issues that arose see Jayampathy Wickramaratne, "Legal Aspects of Devolution in Sri Lanka," in Towards Democratic Governance in Sri Lanka: A Constitutional Miscellany, ed. Jayampathy Wickramaratne (Rajagiriya: Institute for Constitutional Studies, 2014), 137-233. For an indepth study on the working of Provincial councils, see Amarasinghe et al., Thirty Years of Devolution.

Steering Committee, "The Constitutional Assembly of Sri Lanka," 2. 
To assuage fears that a provincial council might use its powers to move towards secession, the Steering Committee proposed that the Centre should be constitutionally empowered to intervene in a province in case there is a 'clear and present danger' to the territorial integrity and sovereignty of the Republic. The following provisions were proposed:

No Provincial Council or other authority may declare any part of the territory of Sri Lanka to be a separate State or advocate or take steps towards the secession of any Province or part thereof, from Sri Lanka.

The President may, on the advice of the Prime Minister, where a situation has arisen in which a provincial administration is promoting armed rebellion or insurrection or engaging in an intentional violation of the Constitution which constitutes a clear and present danger to the territorial integrity and sovereignty of the Republic, by Proclamation-

(a) assume to the President, all or any of the functions of the administration of the Province and all or any of the powers vested in, or exercisable by, the Governor, the Chief Minister, the Board of Ministers or any body or authority in the Province; and

(b) where it is necessary for the effectual exercise of the powers under sub-paragraph (a) of this paragraph, dissolve the Provincial Council.

(c) The proclamation shall include reasons for the making of such proclamation. Such a Proclamation shall be subject to Parliamentary approval and be subject to judicial review. ${ }^{56}$

A very sensitive issue is the extent of devolution in the North and East. The recognition of the North-East as the traditional homeland of the Tamils and the 'merger' of the two provinces has always been a key demand of the Tamil nationalist movement. Tamils live predominantly in the North and the East. In the North, according to the last census, they accounted for more than $95 \%$ of the total population. In the East, they live mainly in the Trincomalee and Batticaloa districts as well as with a significant percentage in the Ampara district. In Batticaloa, the Tamil are the predominant community, but Batticaloa is not contiguous with the North: the Trincomalee district is in between them, and all three communities are found in roughly equal proportions there. The merger is fiercely opposed by the Sinhalese who claim that any 'amalgamation' of the districts would be a stepping stone to secession. Muslims in the East are also opposed to the idea fearing that they would be reduced to a small

${ }_{5} 6$ Steering Committee, "The Constitutional Assembly of Sri Lanka," 26. 
minority in a Tamil dominated North-East. Some Muslims, however, are prepared to consider a merger of the Tamil-dominated areas of the East with the North if the Muslim-majority areas of the East are recognised as a separate devolved unit.

Attempting to strike a balance, Article $154 \mathrm{~A}$ (3) of the Constitution, introduced by the 13th Amendment, allowed Parliament to enact a law providing for the merger of two or three adjoining Provinces. The provincial councils Act, enacted along with the 13th Amendment, provided that the President could make an order on the 'merging' of two or three adjoining provinces, and that a poll would be held on or before 31 December 1988 in the provinces concerned, so that voters could decide whether or not a province should remain linked to the other specified province or provinces. There were two special provisions that applied to a merger of the Northern and Eastern Provinces. The President should not make a Proclamation of the merging of the said Provinces unless he was convinced that (a) arms, ammunition, weapons, explosives and other military equipment owned or controlled by terrorist, militant or other groups with a view to establishing a separate state on 29 July 1987 had been surrendered to the government or to designated authorities, and (b) the hostilities and other acts of violence by such groups in the said Provinces had ceased. Sub-section (3) states if the electors of the Eastern Province decide that such a Province should be linked to the Northern Province, a poll shall not be required in the Northern Province.

As a result, the Northern and Eastern provinces were 'merged' by an order of the President and elections held for the North-Eastern provincial council in 1988. While candidates of the Ealam People's Revolutionary Liberation Front (EPRLF) were undisputedly elected in the districts in the Northern Province, the elections held in the districts of the Eastern Province were more contested. The EPRLF, a separatist militant group that gave up separatism following the Indo-Lanka Accord, set up an administration. During a period of honeymoon talks between the government of President Premadasa and the LTte, the Indian Peace Keeping Force invited by President Jayewardene as part of the Accord and trying to contain the LTTE's military was requested to withdraw from Sri Lanka. The LTTE soon began attacking the EPRLF and other groups which had accepted the Accord and the EPRLF made a rash 'unilateral declaration of independence' which was used by President Premadasa to dissolve the North-East provincial council. Since the 13th Amendment did not permit the premature dissolution of a provincial council except on the advice of the Chief Minister, Parliament hurriedly passed the provincial councils (Amendment) Act No. 27 of 1990. A new provision (Section 5 A) was inserted whereby a provincial council would be dissolved if the Governor made a communication 
to the President stating that more than half of the members of the Council expressly repudiated or manifestly disavowed obedience to the Constitution. The North-East provincial council was accordingly dissolved. Fresh elections to the North-East provincial council were repeatedly postponed by the use of Emergency Regulations. In 2007, the Supreme Court held that the merger of the two provinces was unconstitutional as the pre-conditions for the merger had not been satisfied. ${ }^{57}$

However, with regard to the abovementioned Article 154A (3) of the Constitution, the deadline for carrying out a poll expired on 31 December 1988 and there was no law in force on possible mergers of provinces. Yet, Tamil parties continued to insist on the merger of the North and the East. According to the interim report of the Steering Committee, three options were discussed: (1) the retention of Article $154 \mathrm{~A}$ (3), but with the additional requirement that a referendum of the people of each of the provinces concerned was also required; (2) that the Constitution should not provide for mergers at all; and (3) that the Constitution recognise the Northern and Eastern Provinces as a single Province. ${ }^{58}$ The first option appeared to be the dominant view, but even if the proposal had been included in the new Constitution, Parliament's chances of passing a law on the matter were remote.

Although Kandyan Sinhala leaders were the first to demand a federal structure, that demand fizzled out after Independence was granted in 1948. Thereafter the demand came from the Tamils, as seen above. As Tamils dominate the Northern Province and live in substantial numbers in the East, the two provinces were at the centre of the conflict. The B-C Pact of 1957 referred to above was for the setting up of Regional Councils in the North and East. The D-C Pact of 1968 proposed District Councils for the whole of the country but made special reference to the use of Tamil as a language of administration and land settlement in the North and East. The secessionist movement that emerged in the 1980s also sought to set up a separate State in the two provinces.

In the above background, one would have expected Sri Lankan leaders to focus on devolution for the North and East rather than for the whole country, but they did just the opposite. A.C.S. Hameed, a senior Minister in

57 Wijesekera v. Attorney-General [2007] 1 Sri LR 38.

58 Steering Committee, "The Constitutional Assembly of Sri Lanka," 4. 
the Jayewardene government that introduced the 13th Amendment, stated publicly that when some leaders suggested to Jayewardene that devolution should be limited to the North and East, he responded negatively. Jayewardene thought that devolution only to the North and East would be seen by many as a stepping stone to separation. The 13th Amendment accordingly provided for symmetrical devolution for all nine Provinces. Since then, there has been no serious demand for asymmetrical devolution.

Devolution soon became a demand of the Muslims and Hill Country Tamils as well. An issue raised by them was the dispersed nature of the two communities and their consequent underrepresentation. Recent amendments to the provincial councils Elections Act had addressed this issue to some extent. The interim report of the Steering Committee proposed setting up Community Councils to ensure that at various levels of government and in different geographical areas, the rights of communities which are minorities within such areas would be protected..$^{59}$ Recognition of local authorities as a third tier of government and an implementing agency for specified subjects both of the Centre and the Provinces would also provide dispersed communities more opportunities to take part in government.

Proponents of devolution were demanding that given the nearly thirty years of experience under the 13th Amendment, powers of the Centre and the Provinces finally be clearly defined. The best proposals in regard to devolution came from the Chief Ministers of the seven 'southern' provinces, all of which had a Sinhala majority. The Chief Ministers were all members of the SLFP. In fact, the Chief Ministers' Conference made similar proposals on several occasions.

The main recommendations of the report on the principles of devolution were as follows:

- Principle of subsidiarity: The principle of subsidiarity is accepted and should be a guide in deciding on the allocation of subjects and functions between the three tiers of government.

- Community councils: constitutional provisions shall be made to ensure that at various levels of government and in different geographical areas, the rights of communities which are minorities within such areas are protected. 
- Inter-Provincial cooperation: The Constitution should provide for the possibility of inter-provincial cooperation with regard to matters falling within the executive competence of such provinces.

- Local Authorities: Local Authorities should be recognised as a third tier of government functioning under the provincial councils. While Local Authorities would not exercise legislative power, they would be an implementing agency for specified subjects both of the Centre and the Provinces as prescribed by law.

- Division of powers between the several tiers of government shall be clear and unambiguous: There is general consensus, including among the Chief Ministers who made submissions before the Steering Committee, that powers must be clearly and unambiguously divided and that the present concurrent list should be abolished. This was also suggested in the Report of the ad hoc Sub-Committee on the relationship between Parliament and provincial councils. Parliament may by law provide for the implementation of functions on selected subjects in the reserved list by the Provinces. Parliament or provincial councils may by law or statute provide for the implementation of specified functions within their purview, to be carried out by the Local Authorities. Whether to retain a concurrent list and, if so, what specific subject areas should be included is to be further discussed.

- National Standards, National Policy and Framework Legislation:

- In particular areas, there could be a necessity for the Centre to prescribe National Standards (e.g. healthcare, education, environment) or Framework Legislation (e.g. Local Authorities' constitution, powers, functions, elections). Therefore, the Constitution should identify and include specified items in respect of which the Centre can enact framework legislation or national standards.

- In regard to National Standards, such minimum standards may be prescribed where it is necessary to ensure (a) the enjoyment by citizens of a reasonable minimum standard of living throughout the country; (b) the enjoyment by citizens of a reasonable minimum standard of state service delivery throughout the country; or (c) a reasonable minimum standard of environmental protection throughout the country.

- The Centre may also prescribe national standards by way of regulations under authority of law, in the circumstances specified above. Such regulations shall not be valid unless approved by both Houses of Parliament. The substantive and procedural validity of such regulations may be challenged in the Constitutional Court.

- National Policy should be a matter for the Cabinet of Ministers at the Centre. In formulating National Policy on matters contained in the 
provincial list, the central government shall adopt a participatory process involving provincial councils. Formulation of National Policy on a provincial list matter would not have the effect of the Centre taking over executive or administrative powers with regard to the implementation of the said devolved power. National Policy shall not override statutes enacted by a provincial council in respect to matters on the provincial list. However, in the event that the Centre enacts legislation to give effect to such national policy, in accordance with the constitutional provisions relating to the enactment of legislation on devolved subjects, the relevant provincial council statutes shall be read subject to such national legislation.

- Existing Central legislation on devolved subjects: All existing Central legislation (on provincial list subjects) shall remain in force and shall be applicable to the Provinces until amended or repealed by legislation enacted by the Province, and accordingly, the powers of Ministers and officials exercisable under such legislation shall be exercisable by the corresponding provincial Minister or official.

- New Central legislation on devolved subjects: The Centre may enact legislation on any subject in the provincial list provided all provincial councils agree to such legislation. The Centre should not legislate on matters on the provincial council list with regard to any Province that does not agree to such legislation, without recourse to adequate constitutional safeguards to ensure that powers devolved should not be taken back unilaterally from the Provinces.

- A Second Chamber of Parliament:

- There is general consensus that a Second Chamber should be established, which is largely representative of the Provinces.

- It is suggested that the Second Chamber should consist of fifty-five Members; five from each of the nine provincial councils elected on the basis of a Single Transferable Vote (sTv) and ten Members elected by Parliament again on the on the basis of sTV.

- The Second Chamber shall not have the power to veto ordinary legislation but may refer ordinary legislation back to Parliament for reconsideration. After Bills are placed on the Order Paper of Parliament, they shall be referred to the Second Chamber to obtain its views, if any, prior to the Second Reading.

- No Constitutional Amendment shall be enacted into law unless passed by both Parliament and the Second Chamber, each by a two-thirds majority. If the referendum requirement is triggered, the Amendment shall not be enacted into law unless also approved by the people at a referendum. 
- Constitutional Amendments seeking to amend basic features of the Constitution including fundamental rights and devolution may not be passed except by way of additional constitutional safeguards.

- Governor: Several of the Chief Ministers who made submissions before the Steering Committee were of the view that executive power should be vested in the Board of Ministers, with the Governor playing a largely ceremonial role, while one Chief Minister called for the complete abolition of the position of Governor.

- The Steering Committee is of the view that the Governor should act on the advice of the Board of Ministers other than where the Governor is specifically authorised by the Constitution. The Governor should be appointed by the President. Constitutional provision should be made to prohibit the Governor, while holding office, from engaging in party politics.

- Provincial Public Service:The appointment, promotion, transfer, disciplinary control and dismissal of employees of the provincial Public Service should be matters for an independent provincial Public Service Commission consisting of members approved by the Constitutional Council (which makes recommendations for the appointment of independent Commissions at the Centre). Currently, the Governor may override decisions of the Commission, which is also appointed by him.

- Chief Minister's Conference: It is recommended that a Chief Ministers' Conference, comprising of the Prime Minister and the Chief Ministers of all Provinces be mandated to meet at regular intervals, in order to discuss issues of common concern, and to promote inter-provincial and Centre-Province cooperation. The Prime Minister shall preside at the Chief Ministers' Conference.

The interim report also contained observations and comments by Members of the Steering Committee on the principles and formulations contained in the Report. Prime Minister Wickremasinghe informed the Committee that his party (UNP) would go along with the entirety of the report. The SLFP led by President Sirisena was generally supportive of devolution but its own proposals did not go as far as those of its own Chief Ministers. The SLFP did not subscribe to the interim report. As expected, the Joint Opposition effectively led by former President Rajapakse was not supportive of further devolution, even wanting to decrease some of the present powers of provincial councils. The Tamil Nationalist Alliance (TNA), in which the FP was the dominant partner, while affirming its position that Sri Lanka should be a federal state within a united, undivided and indivisible country, nevertheless stated that in the interests of reaching an acceptable consensus, it was willing to consider agreement with the main principles articulated in the report if the same were acceptable 
to the two main parties. The TNA's position was widely welcomed in the South although it was severely criticised by Tamil extremists.

As stated earlier, there has been little movementsince the Steering Committee presented its interim report. The UNP and the SLFP as well as President Sirisena and Prime Minister Wickremasinghe moved away from each other. In October 2018, the President removed Wickremasinghe as Prime Minister, which he was not empowered to do. Indicative of a new alignment, he appointed Rajapakse as Prime Minister, hoping that cross-overs from the UNP and its allies would give the Sirisena-Rajapakse combination a majority in Parliament. When that did not materialise, Sirisena dissolved Parliament but the Supreme Court held that the dissolution was unconstitutional. Wickremesinghe was later reappointed as Prime Minister. The October 2018 'constitutional coup' dashed all hopes of constitutional reform through the Constitutional Assembly process.

At the Presidential elections held in November 2019, Gotabhaya Rajapakse, Mahinda Rajapakse's younger brother, was elected as President; he is a former Army officer and Secretary, Ministry of Defence, and considered a stronger hardliner than Mahinda. He was enthusiastically supported by Sinhala extremists who were opposed to any devolution and who maintained that there was no 'ethnic problem' in Sri Lanka. Wickremesinghe resigned and the elder Rajapakse was appointed Prime Minister.

At the Parliamentary elections held in August 2020, the Rajapakses, together with allies, obtained a two-thirds majority. This time, their immediate target was to be the 19th Amendment to the Constitution of 2015 which reduced the powers of the President, thereby strengthening Parliament.

Hardliners might press upon the Rajapakses to abolish the provincial councils altogether, but this is unlikely because of the strong Indian factor. During a recent visit of Mahinda Rajapakse to India, Indian Prime Minister Modi urged that the 13th Amendment be implemented in full. What is most likely to happen under the Rajapakses is that provincial councils will stay but under the effective control of the Centre. This unfortunately means that the ethnic crisis will continue to simmer.

Yet another chance for a constitutional settlement has been missed and added to a history of missed opportunities.

\section{Bibliography}

Amarasinghe, Ranjith, Abeysinghe Navaratna-Bandara, Jayampathy Wickramaratne, Naganathan Selvakkumaran and Asoka Gunawardena. Thirty Years of Devolution: An 
Evaluation of the Working of provincial councils in Sri Lanka. Rajagiriya: Institute for Constitutional Studies, 2019.

Bandaranaike, Solomon W. R. D. Ceylon Morning Leader, May 19, May 27, June 2, June 9, June 23, June 30 and July 26, 1926. Reproduced in Power-sharing in Sri Lanka: Constitutional and Political Documents, 1926-20o8, edited by Rohan Edrisinha, Christian Hofer, Lukas Probst, Vikalpa Pratipatti Kendraya and Berghof Foundation for Conflict Studies, 28-53. Colombo: Centre for Policy Alternatives, 2008.

De Silva, G.P.S. Harischandra. A Statistical Survey of Elections to the Legislatures of Sri Lanka, 1911-1977. Colombo: Marga Institute, 1979.

Edrisinha, Rohan, Christian Hofer, Lukas Probst, Vikalpa Pratipatti Kendraya and Berghof Foundation for Conflict Studies. Power-sharing in Sri Lanka: Constitutional and Political Documents, 1926-2008. Colombo: Centre for Policy Alternatives, 2008.

Irwin, Colin. "'War and Peace' and the APRC Proposals." Peacepolls.org (2010). Accessed on October 15, 2013. www.peacepolls.org/peacepolls/documents/oo1173.pdf.

Marasinghe, Lakshman and Jayampathy Wickramaratne. 13th Amendment: Essays on Practice. Pannipitiya: Stamford Lake, 2010.

Mohanasundaram, Ganapathy Palanithurai K., Dynamics of Tamil Nadu Politics in Sri Lankan Ethnicity. New Dehli: Northern Book Centre, 2003.

Wickramanayake, S. S. "The Management of Official Records in Public Institutions in Sri Lanka: 1802-199o." Unpublished PhD diss., University of London, 1992.

Wickramaratne, Jayampathy. "Sri Lanka: Missed Opportunities and the Way Forward." In Towards Democratic Governance in Sri Lanka: A Constitutional Miscellany, edited by Jayampathy Wickramaratne, 485-548. Rajagiriya: Institute for Constitutional Studies, 2014 .

Wickramaratne, Jayampathy. "The 1972 Constitution in Retrospect." In Towards Democratic Governance in Sri Lanka: A Constitutional Miscellany, edited by Jayampathy Wickramaratne, 75-95. Rajagiriya: Institute for Constitutional Studies, 2014.

Wickramaratne, Jayampathy. "Legal Aspects of Devolution in Sri Lanka," in Towards Democratic Governance in Sri Lanka: A Constitutional Miscellany, edited by Jayampathy Wickramaratne, 137-233. Rajagiriya: Institute for Constitutional Studies, 2014 .

Wickramaratne, Jayampathy "Sri Lanka: Missed Opportunities and the Way Forward." In Towards Democratic Governance in Sri Lanka: A Constitutional Miscellany, edited by Jayampathy Wickramaratne, $485^{-548}$. Rajagiriya: Institute for Constitutional Studies, 2014 . 
Jayampathy Wickramaratne - 9789004394612 Downloaded from Brill.com04/26/2023 02:57:23PM via free access 